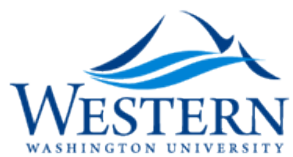

Western Washington University

Western CEDAR

$5-1-1986$

\title{
Interdisciplinary History: A Historiographical Review
}

Harry R. Ritter

Western Washington University, harry.ritter@wwu.edu

T. C. R. Horn

Western Washington University

Follow this and additional works at: https:// cedar.wwu.edu/history_facpubs

Part of the History Commons

\section{Recommended Citation}

Ritter, Harry R. and Horn, T. C. R., "Interdisciplinary History: A Historiographical Review" (1986). History Faculty and Staff Publications. 77.

https://cedar.wwu.edu/history_facpubs/77

This Article is brought to you for free and open access by the History at Western CEDAR. It has been accepted for inclusion in History Faculty and Staff Publications by an authorized administrator of Western CEDAR. For more information, please contact westerncedar@wwu.edu. 


\section{Society for History Education}

Interdisciplinary History: A Historiographical Review

Author(s): T. C. R. Horn and Harry Ritter

Source: The History Teacher, Vol. 19, No. 3 (May, 1986), pp. 427-448

Published by: Society for History Education

Stable URL: http://www.jstor.org/stable/493382

Accessed: 06-10-2015 22:44 UTC

Your use of the JSTOR archive indicates your acceptance of the Terms \& Conditions of Use, available at http://www.jstor.org/page/ info/about/policies/terms.jsp

JSTOR is a not-for-profit service that helps scholars, researchers, and students discover, use, and build upon a wide range of content in a trusted digital archive. We use information technology and tools to increase productivity and facilitate new forms of scholarship. For more information about JSTOR, please contact support@jstor.org. 


\title{
Interdisciplinary History: A Historiographical Review
}

\author{
T. C. R. Horn \\ Harry Ritter \\ Western Washington University
}

I.

FROM THE STANDPOINT of the 1980s it appears that one of the most noteworthy things about professional historical studies in the twentieth century has been their gradual tendency to become increasingly comprehensive in scope and more experimental and eclectic in conception and method. The changes which have already occurred, and seem likely to continue to occur, have been based largely on historians' use of concepts and techniques developed by scholars in other disciplines. In general, the trend has been to look primarily to the "social sciences"-sociology, economics, political science, psychology, and anthropology-for new ideas, and lately to statistics and mathematics; to a lesser degree, historians have turned to "humanistic" disciplines such as language studies, poetics, literary criticism, and philosophy. In this paper we shall discuss some aspects of the origins, growth, and present status of this movement.

At the outset, however, it must be admitted that these changes in orientation, while crucially significant from the overall point of view of history's development as a branch of scholarship, have thus far deeply affected the thinking and scholarly output of only a minority of historians. The British historian Geoffrey Barraclough is correct in stating that "At the moment resistance to change is at least as strong as, in all probability stronger than, the forces making for change. ... At least 90 per cent of historical work published today is resolutely

The History Teacher Volume 19, Number 3 
traditional in method, subject-matter and conceptualization."1 The adjective "interdisciplinary" has been a vogue word for some time now and may even be considered passé in some circles, an outworn relic of the curricular faddism and mania for "innovation" which swept the academic world in the late 1960s and early 1970s. Moreover, there is a vocal lobby within the discipline, preoccupied with "professional identity," 2 which is militantly committed to defending the "autonomy" of historiography against intercourse with other branches of science and scholarship, especially in the form of quantitative research. ${ }^{3}$ To a large degree, the history of twentiethcentury history has been one of struggle between defenders of traditional attitudes established in the nineteenth century (when historians claimed to have emancipated themselves from literature and speculative philosophy) and reformers who self-consciously seek to revolutionize the profession. To date, the conservatives, though perhaps not always as inflexible as the most extreme, are still numerically in the ascendency.

II.

"Interdisciplinary history" means historical scholarship which makes use of the methods or concepts of one or more disciplines other than history. "Discipline"-in the sense of "a branch of instruction or education; a department of learning or knowledge"-is a very old term in English. The earliest use cited by the Oxford English Dictionary comes from the prologue to Chaucer's "Yeoman's Tale" (1386): "Assaye in myn absence this disciplyne and this crafty science." The term derives from the word "disciple" (Latin disciplina) and the idea of "instruction imparted to disciples or scholars." In the vocabulary of twentieth-century academic life the word normally refers to the specialized fields into which instruction and research have been divided in modern university curricula. ${ }^{4}$ The term "interdisciplinary" is of considerably more recent vintage. The $O E D$ defines it as "Of or pertaining to two or more disciplines of learning; contributing to or benefitting from two or more disciplines," and cites a sociological article published in 1937 as the earliest instance of its use. ${ }^{5}$

Nowadays, the term "interdisciplinary" has become common to members of every academic discipline. It has been made familiar in innumerable discussions, and is quite often used to connote something desired, something worthy of achieving in teaching and scholarship. It has become a topical word because of growing fear that the specialized disciplines have seriously narrowed the intellectual outlook of those engaged in teaching and research in their own field of 
knowledge. The word embodies a call to cure this situation, to counteract the baleful results of over-specialization. On reflection, however, it is clear that less specialization is not a possible solution, for it is this very drive towards specialization since the start of the nineteenth century which today has given us precise and accurate knowledge in all of our academic disciplines. The growth of significant knowledge depends upon an accumulation of more and more complex bodies of information, and these bodies of information in turn are the results of more and more complex methods of analysis. What all of this points to is the fact that interdisciplinary teaching and research should not be understood as a way of replacing specialization, but as a new kind of specialization which builds on and integrates the specializations of the discrete disciplines.

American-trained historians have used the term "interdisciplinary" since at least the early 1950 s. $^{6}$ The expression "interdisciplinary history" became fashionable in the 1960s, and was endowed with a measure of professional acceptance with the founding of The Journal of Interdisciplinary History in 1970 (a methodologically related journal, Comparative Studies in Society and History, had already been founded in 1958). The underlying concept of interdisciplinary history considerably antedates introduction of the term itself, however. In order to understand the rise and development of the concept of interdisciplinary history it is helpful to say something about the traditional model of historical scholarship established in the nineteenth century.

Nineteenth-century historical research, allowing for notable exceptions such as Jacob Burckhardt's famous Civilization of the Renaissance in Italy, was strongly and narrowly oriented toward politics, the evolution of institutions, the role of political personalities, and the narration of discrete events-what the turn-of-the-century French scholar Paul Lacombe dubbed "l'histoire événementielle" (the "history of events"). The situation was aptly reflected in E. A. Freeman's famous opinion that history is simply "past politics." Though historians did not completely ignore the non-political aspects of the pastsocial structure and development, cultural affairs, the history of thought, etc. - they tended to treat them "for the most part as an impressionistic 'backcloth,' roughly sketched in, against which the drama of political events was played out." The tradition of equating history with the narration of political events is, of course, ancient; it reaches back to historiographical models established by Thucydides and Polybius, to the Greco-Roman notion that history's chief purpose is to provide political lessons for future statesmen, and to the theory of historical understanding found in Aristotle's Poetics, 
according to which history (in contrast to the higher occupations of poetry and philosophy) deals with particular events rather than general truth. This venerable tradition was powerfully reinforced in the early nineteenth century, at precisely the time history was establishing itself as an academic profession as opposed to a gentleman's avocation or pursuit for active or retired politicians. The new business of academic historiography, which emerged first in the universities and archives of Germany and France, was based on the close analysis of written documents, and the kind of documentation most readily available to disciplinary "role models" such as Leopold von Ranke and Fustel de Coulanges was political and diplomatic. This naturally conditioned the kind of history they wrote.

Moreover, these early continental historians, men who set standards for the later professionalization of history in England and the United States, were bureaucrats whose job was to provide their countries with historical pedigrees and national heroes, so it is hardly surprising that their work focused on political and institutional matters. The rank-and-file scholars who followed in the footsteps of pioneers such as Ranke and Fustel were, by and large, uninterested in the underlying epistemological problems of their new science; they were primarily engaged in the collection and organization of facts, and in the publication of scholarly monographs on carefully delimited topics. The spirit of patient caution and fact-grubbing empiricism which animated research is well illustrated in a statement of 1876 by the French scholar Gabriel Monod:

We have understood the danger of premature generalizations, of great a priori systems that claim to cover everything and explain everything. We have sensed that history should be the object of a slow methodical process of investigation in which one moves gradually from the particular to the general, from details to the whole; where all obscure points are successively illuminated in order to have the whole picture and to be able to base general ideas, susceptible to proof and verification, upon groups of established facts. ${ }^{8}$

In the late nineteenth century, German philosophers such as Wilhelm Dilthey, Wilhelm Windelband, and Heinrich Rickert developed a neo-idealist theory of historical knowledge which in some ways dovetailed with the assumptions of non-theoretical, "working" historians. This theory was founded on a radical distinction between the "natural" and "cultural" sciences (Naturwissenschaften and Geisteswissenschaften). ${ }^{9}$ According to the classic formulations of Windelband and Rickert, the natural sciences were "nomothetic," i.e., con- 
cerned with the systematic search for general laws of physical nature, whereas the cultural sciences (notably history) were "idiographic," i.e., they sought to understand human affairs in terms of the unique, non-repeatable contexts in which they occurred, rather than in terms of generalizations and regularities. The ultimate task of history was the largely intuitive and empathetic "understanding" (Verstehen) of particular and unique events, situations, and personalities of the past. Thus, history was set off clearly from natural science, something which flattered historians' sense that they were engaged in a distinctly special and "autonomous" kind of work. History was still considered a "science," it was simply a very different kind of science than, say, chemistry or physics. This theory continues to exert a strong influence on the self-image of many historians today, although the radical distinction between "nomothetic" and "idiographic" forms of knowledge is now widely discredited. ${ }^{10}$

\section{III.}

It is against this background that the rise of the concept of interdisciplinary history must be understood. Key manifestations of the idea at the turn of the twentieth century were, in Germany, the work of Karl Lamprecht (1856-1915); in France, the movement for historical "synthesis" founded by Henri Berr (1863-1954); and, in the United States, the crusade for a "New History" led by James Harvey Robinson (1863-1936). In each case we find a self-conscious rebellion against the prevailing orthodoxy that the historian is basically a narrator of particular events which occurred in the past and against the belief that history is a discrete kind of inquiry whose methods, goals, and purposes differ in kind from those of natural science. In each case it was claimed that history must borrow ideas from other fields, especially from the new family of empirical "social sciences" being institutionalized in the 1880 s and 1890 s. It should also be noted that each of the turn-of-the-century appeals for interdisciplinary cooperation, and especially that of Berr, was in some direct or indirect way indebted to the mental orientation known as "positivism," an outlook associated particularly with the name of the mid-nineteenth century French social theorist August Comte. Comte and his historiographical followers (notably H. T. Buckle in England) believed that history could, and should, be placed on the same epistemological plane as the natural sciences, which Comte idealized for their capacity to proceed from the empirical analysis of observable phenomena to the formulation of universal laws. In the late nineteenth century, Comte's philosophy was widely discredited among historians and 
many others, including the neo-idealist philosophers, but his conviction that all paths to knowledge are essentially similar persisted and became a basic assumption of the first generation of interdisciplinary historians.

Karl Lamprecht was an idiosyncratic and astoundingly prolific German historian who taught at the University of Leipzig from 1891 to his death in 1915. Lamprecht used the term "cultural history" (Kulturgeschichte) as an umbrella label to designate his idea of a comprehensive approach to the study of the past, based on a potpourri of the findings and concepts of traditional history, economics, art history, and psychology - especially the psychology of Wilhelm Wundt and Theodor Lipps. The Leipzig scholar was among those late nineteenth-century intellectuals who, in the face of growing specialization, "felt the need for a more systematic and comprehensive view of all new knowledge and diversified concerns"; his basic question was "how could the history of the many diverse activities of man be brought together in one unifed form and intelligible structure?"1 $\mathrm{He}$ regarded psychology as especially important, and defined his version of cultural history as "the comparative history of the factors of socio-psychic development." 12 For psychology to be genuinely useful for historians, however, he believed that it must be transformed into a collective "social psychology," one which focused on groups and situations rather than single personalities. In 1905 he formulated the basic principle of his orientation: "Modern historical science is above all a social-psychological science."13 To this fundamental principle, Lamprecht wedded the eighteenth-century concept of Volksgeist ("national spirit") and made this idea, which he re-christened Volkseele ("national psyche"), the fundamental object of his research. His grandiose, twenty-one volume Deutsche Geschichte (1891-1915) was designed to trace the course of development of the collective German psyche through a progression of stages from antiquity to the present. He believed it would ultimately be possible to write a general history of the psychic development of mankind which would exhibit a universal pattern; for the moment, however, historians would have to begin with individual histories of national psychic development.

Lamprecht's unorthodox ideas provoked a furious and often not very edifying Methodenstreit among German historians prior to World War I, and these ideas were eventually totally discredited as "eclectic trifling."14 It is only since the 1960s that a new generation of historians in West Germany, itself in conscious revolt against traditional ideas, has taken a renewed interest in his theory; even now his approach is viewed essentially as a matter of antiquarian curiosity. It is generally agreed that Lamprecht's vision was too vast for the 
methods available to him (social psychology and statistics, for example, were still in their infancy), that his promethean vision was too grandiose, vague in conception, and based on time-bound, now discredited assumptions, and that his books were feverishly produced without careful attention to factual accuracy. The psychological doctrines to which Lamprecht appealed are now considered to have been superseded, and even Wundt, the author of many of the ideas he sought to use, stated that "as a psychologist [Lamprecht] went his own ways. ... The psychology in which he lived simply was not one which seeks to explain connections between psychic phenomena through an analysis of them, but it was the intuitive psychology of the artist."15

Lamprecht left no enduring legacy in Germany, but his ideas had an important impact in the United States, where they helped to inspire the so-called "New History" which blossomed on the eve of the First World War. A key feature of this doctrine, which flourished from ca. 1912 (the publication date of James Harvey Robinson's The New History) to the mid-1930s, was the call for an "enthusiastic alliance with the social sciences."16 In the characteristically American terminology of Robinson, the New History's foremost advocate:

History's chances of getting ahead and of doing good are dependent on its refraining from setting itself off as a separate discipline and undertaking to defend itself from the encroachments of seemingly hostile sciences which now and then appear within its territory.... The bounds of all departments of human research and speculation are inherently provisional, indefinite, and fluctuating; moreover, the lines of demarcation are hopelessly interlaced. ... Each so-called science or discipline is ever and always dependent on other sciences and disciplines. It draws its life from them, and to them it owes, consciously or unconsciously, a great part of its chances of progress. ${ }^{17}$

Another champion of the new approach, Harry Elmer Barnes, sought to bring the community of historical scholars abreast of the latest developments in the various fields of social science. ${ }^{18}$ Others prominently associated with the movement at different times were Charles Beard, James T. Shotwell, Conyers Read, Frederick J. Teggart, and Crane Brinton. For these men, the expression "New History" became a battle-cry which designated a "synthetic," present-oriented, pragmatic approach to the past which was pitted, often quite belligerently, against the "political fetish" of late nineteenth-century historiography. ${ }^{19}$

The impact of the New History on historical studies in the United 
States was much greater than the impact of the isolated Lamprecht's ideas on German historiography. As a label for innovators, it is true, the term began to lose favor in the mid-1930s, when the movement as a whole became discredited due to its association with presentism, relativism and "indiscriminate eclecticism." 20 Since 1945 much of the commentary on the movement has been critical and ironic in tone, ${ }^{21}$ and it is probably true that the achievements of the New History were more notable in the sphere of manifestoes and programmatic statements than in the production of works which actually demonstrated its ideas in practice. Still, the New History unquestionably helped to reorient thinking and pave the way for a broader and more methodologically eclectic view of history in the period since 1945. Indeed, Barnes was not entirely wrong when he assumed, in the second edition of his $A$ History of Historical Writing (1962), that the principles of the New History, in particular the interdisciplinary principles, had, in fact, triumphed.

A third, and in some respects the most important, manifestation of turn-of-the-century interdisciplinary historical theory arose in France under the leadership of the philosopher and entrepreneur of cooperative research, Henri Berr. Berr, who founded the Revue de Synthèse Historique in 1900, described his program for "historical synthesis" as "basically an appeal for greater cooperation between social scientists and historians." 22 The core of his approach is reflected in his statement of 1900 that "Historical synthesis is . . intended . . to induce ... various teams, together, each to perform its particular function and to be of greater mutual assistance through a clearer conception of the common task." 23

Berr's Revue de Synthèse became an international forum for the discussion of new theories and novel research in a variety of fieldspsychology, sociology, anthropology, and philosophy, as well as history. Among its contributors were the sociologist Emile Durkheim, the philosopher Benedetto Croce, and the aforementioned historian Lamprecht. Berr countered criticism that his crusade was too ambitious with an interesting darwinist argument:

Among living seeds only a small number ever develop. Among ideas, in like wise, an inevitable process of selection takes place; and a program must be too rich in order to be sufficiently so [emphasis added]. It is through the development of the Revue that we shall see what is fated to prosper and what has no future. ${ }^{24}$

Berr was convinced that the organization and coordination of 
research was a crucial task and, like Lamprecht, he was especially interested in a union between history and psychology:

It seems [he wrote], that these various undertakings, amalgamated through historical synthesis, must lead ultimately to psychology. The comparative study of societies must lead to social psychology and to a knowledge of the basic needs to which institutions and their changing manifestations are the response. ${ }^{25}$

The interdisciplinary momentum generated by the Revue de Synthèse helped create the atmosphere in which the now famous "Annales school" of French historiography originated. This movement, led by Lucien Febvre and Marc Bloch (co-founders of the Annales d'Histoire Economique et Sociale in 1929), was based on the idea that history

must be wide open to the findings and methods of other disciplines-geography, economics, sociology, psychology - and at the same time must resist the temptation. .. to divide itself into a number of "specialisms" (economic history, the history of ideas, etc.) each going its own independent way. ${ }^{26}$

Febvre, originally a member of Berr's circle, emphasized that "What we need are alert, inventive and ingenious brains looking for alliances; men who, when they come across any intellectual work, ask themselves. . 'What use can be made of this though it was not made for me?" 27 Since the 1930s, the Annales school has been the historiographical avant-garde in France; indeed, it is now virtually the reigning orthodoxy, and its leaders have "promoted a view of history resting on the close collaboration of all the human and social sciences, to which the special contribution of the historian is le sens $d u$ temps." 28 In 1947 Febvre was named president of the newly-created "Sixth Section" of the French Ecole des Hautes Etudes, the aim of which was to "promote research and teaching of the most advanced kind in the area of economics and the social sciences" 29 and to encourage the kind of interdisciplinary teamwork which Berr had championed as a private intellectual impresario. Under Febvre's direction and that of his successors, the "Sixth Section" became the world's single most important center for the development of interdisciplinary theory, methodological innovation (notably in the areas of quantitative or "serial" analysis, historical demography, and the historical study of collective psychology [mentalités]), research, and publication. By the 1960 s the international reputation of the Annales school-one might even use the word mystique — had grown to such 
an extent that it had become the major source of inspiration to advocates of interdisciplinary history in West Germany, Eastern Europe, England, and the United States.

IV.

The importance of figures such as Lamprecht, Robinson, Berr, and even Bloch and Febvre, at least from the point of view of our subject, lies mainly in the gradual creation of a climate of thought open to the possibilities of interdisciplinary exploration. For all of their programmatic emphasis on the importance of cross-disciplinary work, their own publications, methodologically speaking, were surprisingly conventional. Berr was really a publicist, not a historical scholar; and despite Lamprecht's genuine theoretical radicalism, his monumental Deutsche Geschichte was filled with "plain historical narrative," a great deal of it "rephrased material borrowed from the works of others."30 Febvre, while calling for team-produced, socio-psychological histories of sensibilité and collective mentalités, was really a rather traditional historian of ideas who worked impressionistically, alone, using time-honored methods of textual criticism. Bloch, perhaps more innovative methodologically, was also basically a private scholar rather than a team worker. Even today, there is doubtless more talk about the need for interdisciplinary history than actual production of interdisciplinary work.

As far as pioneers such as Lamprecht and Berr were concerned, the problem was to some extent simply the fact that methods and concepts did not yet exist to do what they wanted to do. Social psychology was still in its infancy, and the computer revolution had to await the end of World War II. ${ }^{31}$ It has really only been since 1945, and especially since 1955, that a major shift in the direction of consciously interdisciplinary practice has occurred, something made possible in large part by the refinement of statistical techniques and the development of other quantitative methods, and by computer technology. A detailed analysis of the achievements of interdisciplinary historical research since 1945 would require another lengthy paper; here it is only possible to briefly characterize some of the main points of focus typical of research in West Germany, the United States, and France.

In view of the determination with which Lamprecht's ideas were opposed in Germany prior to World War I, it is not surprising that interest in interdisciplinary work has grown very slowly in post-1945 West Germany. Much of the energy of the West German historical profession in the period since 1945 has been exerted in the production of ideologically revisionist but nonetheless methodologically conven- 
tional diplomatic and political histories which reassess Germany's role in twentieth-century affairs. The classic example is Fritz Fischer's now famous study of Germany's Aims in the First World War (1961) - radical in its attack on the patriotic, state-oriented historiography of traditionalist scholars such as Friedrich Meinecke and Gerhard Ritter, but completely conventional in its methodology. Significant interest in quantitative methods developed only in the 1970 s, and is still in its infancy. Most interdisciplinary work has been inspired by the example of historically-oriented political sociology, ${ }^{32}$ which stems primarily from the native sociological tradition established by Max Weber, Werner Sombart, Georg Simmel, and Josef Schumpeter in Lamprecht's time, but which was largely ignored by historians until the 1950s because "social" history was identified with "socialist" history. The Weberian approach is based on the use of now familiar "ideal typical" concepts, i.e., idealized characterizations of social groupings and phenomena, intellectual climates, etc., which are abstracted from actual historical situations and used for purposes of comparative historical analysis. The best known examples are Weber's own concepts of the "Protestant ethic," "capitalism," and "bureaucracy." One of the best recent German examples of the historiographical use of Weberian ideal types is Hans Rosenberg's Bureaucracy, Aristocracy, and Autocracy (1958), a book which analyzes the development of the Prussian bureaucracy in the seventeenth and eighteenth centuries. Among other things, Rosenberg uses the now commonly-accepted sociological device of the "case study" as a springboard for his generalizations, in this instance the mid-eighteenth century jurist Samuel von Cocceji provides him with a "representative" individual who is treated as a model, or "ideal type," for the eighteenth-century Prussian bureaucracy as a whole. Rosenberg, it is true, wrote the book while living in the United States, but he was German-born and trained, and his work has been a major influence in establishing a tradition of sociological history in post-war West Germany.

Also noteworthy in this connection is the revival of interest in the works of hitherto neglected German historians, e.g., Eckart Kehr (1902-1933), whose works reversed the previous dominance of "foreign policy" over "domestic politics." Kehr insisted upon the importance of domestic tensions, class conflicts, social and economic considerations, etc., as shaping influences on German foreign policy, especially during the Wilhelmine era. Such researches encouraged the post-World War II movement in the direction of social and economic history, and the use of the methods of social science, long familiar in French and Anglo-American scholarship. See, for example, the work 
of the contemporary West German historians Hans-Ulrich Wehler and Jürgen Kocka.

Finally, it should be said that Marxian social theory has become quite influential in West Germany, and there has been a growing dialogue between East and West German historians since the normalization of diplomatic relations between the two Germanies in the early 1970s. The fact that Marxian historical materialism has only recently begun seriously to influence German historical studies is an indication of the persistence of traditional attitudes; outside of Germany, historical materialism began to exert significant influence as early as the 1890s. It should be recognized, however, that Marxism itself is a product of the nineteenth-century German idealist and historist traditions and has often been militantly opposed to so-called "bourgeois social science" in the twentieth century, especially sociology. Thus, Marxian influence has sometimes hindered interdisciplinary exploration. But, on the whole, it has probably helped; one might generalize and say that the methodology of the interdisciplinary avant-garde in West Germany today is a hybrid of Weberian sociology and Marxian social theory.

In the United States there has long been considerable interest in Weber's ideas, which were translated from the German for American scholars by Talcott Parsons in the 1930s. As far as Marx is concerned, his influence, always controversial, was felt as early as the turn-ofthe-century in the work of such writers as Charles Beard. Among post-1945 innovators in the United States, the "distinguishing feature" has been the "steadily advancing alignment between history and the social or behaviorial sciences." 33 This trend was stoutly debated, as reflected in the heated response to a series of reports prepared by social scientifically-oriented historians for the Social Science Research Council in 1946, 1954, and 1963. Despite much initial resistance, interest in communication with other disciplines helped feed the growth of the idea of "area studies" in the 1950s and 1960s, in which representatives from a number of disciplines came together in institutes to study particular regions of the world. (This was also encouraged by foreign policy considerations; in its new role as world policeman the American goverment promoted cross-disciplinary teamwork to serve perceived global interests.) The founding of the interdisciplinary journal Comparative Studies in Society and History in 1958 was a by-product of these trends.

Recent interdisciplinary work in the United States has been perhaps most far-reaching in its implications in the area of quantitative studies: ". . . it remains the outstanding contribution of the United States," writes Barraclough, ${ }^{34}$ "to have demonstrated to the world at 
large the important part which data analysis, numerical techniques, ecological correlation, econometrics, and other more sophisticated conceptual tools are able to play in the historian's work." This is especially true in the field of economic history where, since the late 1950 s, there has been a productive cross-fertilization between history and quantitative economics. In this case, historians adapted computer-related model building techniques, methods of statistical projection, and counterfactual analysis developed by theoretical economists for use in the study of past rates of economic growth and a variety of other specific problems. Perhaps the best known example is Robert Fogel and Stanley Engermann's Time on the Cross, a study of the economics of slavery in the Antebellum American South. The approach remains controversial, and even some of its most ardent champions of the 1960 s have tempered their views. ${ }^{35}$ Still, there are at least two reasons why the importance of "cliometrics"(or "econometric history") cannot be denied. First, its advocates have persuasively argued that all history, even the most traditional kind, is in some degree quantitative; the idea of measurement is implicit in the use of words such as "more," "less," "decisive," "important," "relatively," and other common terms of comparison which are simply unavoidable for historians, or anyone else for that matter. If the means exist to make the terms of quantitative statements more explicit and precise, it only makes sense to use them. Secondly, econometric history has proven fruitful for testing conventional interpretations. A wellknown example is Fogel's use of counterfactual analysis to challenge the generally-accepted belief that the construction of railroads was essential to American economic development in the nineteenth century. ${ }^{36}$

Before leaving the American scene, mention should be made of efforts undertaken (primarily in this country) to adapt Freudian and post-Freudian psychoanalytic theory to historical purposes, and to create a new interdisciplinary field of "psychohistory." Thinking along these lines developed quite early in the United States (witness Preserved Smith's psychoanalytic study of Luther's early development published in 1913), and peaked in the 1960s following the appearance of Erik Erikson's widely admired study, Young Man Luther (1958), which used the adjective "psycho-historical" to describe the author's historical application of his own post-Freudian "ego psychology." 37 Down to the present, however, most historians have been particularly skeptical of this movement. Two objections continue to seem crucial: 1) psychoanalysis depends largely on the discovery and interpretation of suppressed childhood traumas, and reliable evidence regarding the early years of most historical personal- 
ities is either scanty or nonexistent; 2) psychoanalysis was a creation of late nineteenth-century central European thought, and attempts to apply the psychoanalytic model to earlier periods seem particularly susceptible to the cardinal sin of historiography - anachronism, or the reading of present assumptions back into earlier eras. Thus the professional respectibility of this form of interdisciplinary scholarship is currently "not yet secure," [But see Lewis Perry, "Has Psychohistory Come of Age?" The History Teacher, 19/2 (1986).-Ed.] and psychohistory is "still more a matter of theoretical discussion by social scientists than of scholarly practice by historians." 38

Turning to France, there have been striking developments in the use of quantification, the "dominant preoccupation" of the Sixth Section of the Ecole des Hautes Etudes. ${ }^{39}$ This is particularly true with respect to the economic history of the early modern period, when governments did not keep extensive statistics of any kind. Much energy has been invested in studies of price fluctuations and middlerange economic trends ("conjunctures") in the seventeenth and eighteenth centuries which help to illuminate the general conditions of material life. It is now possible, as a result, to speak with some assurance about the material conditions of social life as a whole, whereas knowledge was previously largely restricted to those groups for which extensive written records existed, namely the literate middle and upper classes. Needless to say, even our understanding of these groups has been greatly enhanced by quantitative social research.

By the same token, achievements in the new field of quantitative historical demography have been striking, and have enormously broadened the horizon of possiblities for social history. In the early 1950s French scholars developed statistical techniques which enabled "family reconstitution" for early modern times, based on the use of parish registers. ${ }^{40}$ These techniques have made possible a whole spectrum of regional work on population: birth and death rates, family size, etc. There has also been a major effort to translate Febvre's call for the creation of a history of social "mentalities"-something which goes beyond the conscious ideas of a relatively small circle of political and intellectual leaders-into quantitative terms, and there have been quantitative studies of pre-industrial popular literature using content analysis, quantitative studies of the publishing industry, etc. ${ }^{41}$ Finally, French historians have taken the lead in efforts to open a dialogue with the natural sciences; this sort of interaction has been especially noteworthy in the field of the history of climatic change. ${ }^{42}$ The results of much of this exciting French work in interdisciplinary history are now readily available to the general English reader in Isser 
Woloch's new text, Eighteenth-Century Europe: Tradition and Progress (1982), which includes an annotated bibliography.

One might conclude this section of this essay with a comment on the contrasting character of interdisciplinary work in France and the United States. In France, due to the existence of strong bureaucratic traditions, the creation of the Sixth Section, and the tradition of social-scientific teamwork, historians have tended to focus on certain generally agreed upon periods and problems, and the sum total of their work gives the impression of order, coherence, and consensus. In the United States, historians have not been centrally organized in a government-sponsored research institute, and they have focused, in laissez-faire fashion, on a wide variety of individually chosen problems. ${ }^{43}$

\section{V.}

At the beginning of this essay, we noted that historians have generally tended to think of interdisciplinary history as being "social scientific" in nature. The emphasis in Barraclough's recent survey of historical studies, for example, is exclusively on social science. We would now like to briefly call attention to recent "interdisciplinary" work utilizing approaches typical of disciplines referred to in the United States as "humanistic." It must be observed, however, that the distinction between the "social sciences" and the "humanities" is in many respects unnecessary and misleading. American-trained historians have spent a remarkable amount of time on the largely irrelevant question of whether history is a "social science," one of the "humanities," or something entirely unique. The distinction is, after all, largely peculiar to the English-speaking world, and one might wonder why the term "science," understood in the traditional sense of an organized body of knowledge, would not serve as a covering label for all these scholarly activities, as it generally continues to do in continental Europe. E. H. Carr has correctly said that "scientists, social scientists and historians are all engaged in different branches of the same study: the study of man and his environment, of the effects of man on his environment and of his environment on man." 44

At any rate, a pioneering role in "humanistic" interdisciplinary studies was played by the "history of ideas" school established in the United States by Arthur O. Lovejoy in the 1920s and 1930s, culminating in the establishment of the Journal of the History of Ideas in 1940. As Lovejoy noted in the first number of that periodical, intellectual history cannot confine itself to the subject matter of any one discipline, for 
the departmentalization - whether by subjects, periods, nationalities, or languages - of the study of the history of thought corresponds, for the most part, to no real cleavages among the phenomena studied. The processes of the human mind, in the individual or the group, which manifest themselves in history, do not run in enclosed channels corresponding to the officially established divisions of university faculties . . . ${ }^{45}$

Lovejoy's journal became a forum for interdisciplinary work by historians, students of political theory, literary critics, and philosophers, and the "history of ideas" helped to popularize the "American studies" approach to United States history, which brought together historians and historically-oriented literary critics. The movement had some impact on university curricula in the 1950s and 1960s, when a number of American studies programs were founded across the country.

At the time Lovejoy was launching his journal, a development took place in analytical philosophy which held considerable promise for history, particularly for the interdisciplinary study of the history of history itself; that promise has yet to be fully realized. This was the establishment of a branch of philosophy which has come to be called "critical philosophy of history," and its birth was signaled by the publication of two studies: Maurice Mandelbaum's The Problem of Historical Knowledge (1938) and Carl G. Hempel's "Laws and Explanation in History" (1942). These essays shifted the focus of discussion in philosophy of history from the "speculative" planei.e., the question of the "meaning" of history (understood as the entire course of human events) to the "analytical" level, i.e., the epistemological foundations of history (understood as a scholarly activity). Hempel's article, in particular, caused a vigorous debate over the nature of historical reasoning, centering around the question of whether or not historians ultimately depend (as Hempel argued) on an appeal to general laws for their explanations. Most historians ignored the debate, either because they had been conditioned to believe (partly as the result of the work of Dilthey, Windelband, Rickert, and Croce, more as a consequence of non-theoretical training in the so-called "Rankean method") that general laws had no place in history on any level; because they believed (with much justification) that most analytical philosophers were actually not acquainted with the way historians traditionally work; or because they believed that the whole question of the grounds of historical knowledge was irrelevant to the writing of good history. The British historian G. R. Elton voiced a widespread opinion when he said that "a philosophic concern with such problems as the reality of historical 
knowledge or the nature of historical thought only hinders the practice of history," and complained that the problem of philosophical inquiries was that they "do not advance the writing of history." 46

This situation is unfortunate for, regardless of one's position vis-avis Hempel's thesis, the philosophical debate opened up the whole question of the nature of history as an activity, a subject upon which historians have traditionally been reluctant to reflect. C. Vann Woodward, one of the minority of leading historians to have taken such matters seriously, lists among the "occupational shortcomings of long standing" of historians, the fact that

their premises are often unexamined, their hypotheses illdefined, their concepts vague, their interpretations confused. The storms of philosophical discourse concerning their basic assumptions and principles go on over their heads. ${ }^{47}$

The few historians and philosopher-historians who have taken critical philosophy of history seriously have sometimes produced illuminating work, e.g., Murray G. Murphey's Our Knowledge of the Historical Past (1973) and Hayden White's Metahistory: The Historical Imagination in Nineteenth-Century Europe (1973). There is, in our view, much room for more interdisciplinary exploration in the areas where historiography (i.e., the history of historical writing), critical philosophy of history, and intellectual history overlap.

A third general area from which historians have occasionally drawn concepts and methods, one in some respects related to critical philosophy of history, is the general field of language studies, linguistics, and poetics. Many historians seem reluctant to look in this direction because these fields are associated with rhetoric and literature, subjects which, like philosophy, history is supposed to have "outgrown" in the nineteenth century. The unavoidable fact remains, however, that historians are at bottom writers of words, and a work of history is, in the most basic sense, a "verbal structure in the form of ... narrative prose discourse." 48 French critics, notably Roland Barthes, have devoted serious attention to the nature of narrative, including historical narrative, and some scholars have been encouraged to apply the concepts of contemporary linguistics and stylistics to the writing of history on a major scale. ${ }^{49}$ In his book Metahistory, for example, Hayden White has devised an ingenious, sometimes cumbersome and abstruse, but often illuminating model of the nineteenth-century European "historical imagination"-an amalgam of ideas drawn from the history of ideas, literary criticism, structuralist linguistics, poetics, traditional rhetoric, and critical philosophy of 
history.

\section{VI.}

It seems appropriate to conclude this survey with an assessment of the extent to which interdisciplinary history has established itself in the historical profession today. One way to measure the degree of acceptance presently enjoyed by the interdisciplinary approach is to review the kinds of books which were recently awarded prizes. If we pick out any number of recently published studies in the field of history, and then consider what the authors' peers find most praiseworthy in them, we will have a rough idea of what may be some of the current trends in the writing of history. For instance, we can choose for consideration the prizes which the American Historical Association awarded for outstanding publications during a recent year1982.50 The awarding of these prizes will give a fairly good indication of what the profession at the highest level considers to be meritorious work.

In 1982, the Herbert Baxter Adams Prize for the best work in ancient, medieval, or early modern European history was awarded to Edward Muir (Syracuse University) for his Civic Ritual in Renaissance Venice (Princeton University Press). The prize committee's citation praised Muir's book as an example of the imaginative use of anthropology to illuminate historical phenomena. Muir used anthropological concepts to interpret Venetian myths, processions, and holidays in such a way as to clarify the unspoken and unstated dimensions of Venetian politics and of the city's conception of the significance of its own past.

The 1982 Albert J. Beveridge Award for the best book on the history of the United States, Canada, or Latin America was given posthumously to Walter Rodney for his History of the Guyanese Working People, 1881-1905 (Johns Hopkins University Press). The committee described the book as one which "integrates material conditions, social structure, and politics to provide a total view of working-class experience in a colonial setting," and an excellent example of recent historical interest in "history from the bottom up." The Albert B. Corey Prize for the best book on Canadian-American relations and affairs went to Guildo Rousseau (l'Université du Québec à Trois-Rivières) for his book on L'Image des Etats-Unis dans la littérature québecoise, 1775-1930 (Editions Naaman). The committee reported that Rousseau used a wide variety of literary sources covering a period of one hundred fifty years to elucidate Quebec's perception of the United States, and to delineate the domi- 
nant themes of the changing attitudes that Canadians have had of Americans.

The John H. Dunning Prize in United States history went to David Jeremy (London School of Economics) for his book on The TransAtlantic Industrial Revolution: The Diffusion of Textile Technologies between Britain and America, 1790-1830 (MIT Press). The prize committee described the book as a "landmark study" in the history of technology and its diffusion in which the author tried to investigate the broader historical circumstances that affected the transfer of technology, and thereby shed new light on the question of the origins of American industrialization.

The Howard R. Marraro Prize for the best work on Italian history, Italian cultural history, or Italian-American relations was given to Eric Cochrane (University of Chicago) for his Historians and Historiography in the Italian Renaissance (University of Chicago Press). Cochrane used a wide variety of written source materials, many of them literary, and relied heavily on important works in the history of the Italian language and literature. His study is an important contribution not only to the field of Italian historiography, but to the general history of Italian literature as well.

These prize-winning books testify to the fact that, on the highest level, the interdisciplinary orientation has solidly established itself in present-day historical writing. Clearly the best history now includes a wide range of subject matter, and current practice in historical research makes use of the results of many kinds of methods of analysis. As we indicated at the outset, the use of methods and concepts developed in other disciplines is still either ignored or repudiated in many professional circles; nevertheless, it is clear that, at the highest level, interdisciplinary history has firmly established itself. This may foreshadow the beginning of a period when the idea of an interdisciplinary approach advances beyond the stage of controversy. Of course, the historian's choice of subject will determine how much consideration he will give to methods other than those of history, and to information derived from a wide range of scholarship. But even such traditional subjects as political, diplomatic, and military history can no longer be fully understood without due regard for sociology, economics, and anthropology. Good diplomatic history today usually must attend to the problems of domestic politics, social conficts within nations, economic conditions both domestic and international, etc. Similarly, the best and the most thoughtful military history written today (e.g., the works of Michael Howard and Michael Roberts) have dealt with more than strategy, tactics, and the movements of armies on the field of battle. The interest which these works 
have generated rests partly on the way they have woven into their discussions of warfare the political and socio-economic aspects of debates on armaments policy, the social and political composition of officer corps and rank-and-file troops, the economic foundations of military power, and even the political and ideological considerations of combat doctrine and strategy.

In principle, then, the question of whether or not the historian should use the ideas and methods of other fields is no longer at issue. The question is, rather, how well the historian selects and makes use of those concepts and techniques.

\section{Notes}

1. Geoffrey Barraclough, "History," in Jacques Havet (ed.), Main Trends of Research in the Social and Human Sciences, Pt. 2, Anthropological and Historical Sciences, Aesthetics and the Sciences of Art (Paris, 1978), p. 435; see also C. Vann Woodward, "History and the Third Culture," Journal of Contemporary History, 3 (1968): 23-4.

2. Woodward, "History and the Third Culture": 27.

3. E.g., Carl Bridenbaugh, "The Great Mutation," The American Historical Review, 68 (Jan. 1963): 315-31; Jacques Barzun, Clio and the Doctors (Chicago, 1974).

4. On the rise of the modern system of compartmentalization of knowledge in American universities, see Alexandra Oleson and John Voss, The Organization of Knowledge in Modern America, 1860-1920 (Baltimore, MD, 1979). While the essays here deal primarily with the situation in the United States, there is much valuable information on the specialization of knowledge in Europe as well.

5. Suppl., vol. 2, 1976. See also H. Holzhey, "Interdisziplinär," in Joachim Ritter and Karlfried Gründer (eds.), Historisches Wörterbuch der Philosophie, 4 (1976): 476-7, which includes a bibliography of German, French, and English titles.

6. E.g., David M. Potter, People of Plenty: Economic Abundance and the American Character (Chicago, 1954), p. xxvi. Historiographical usage probably antedates this example, since Potter refers to "the present academic zeal for interdisciplinary study and cooperative effort across departmental lines."

7. Barraclough, "History": 283.

8. Cited in Henri Berr, "About Our Program" [1900], in Fritz Stern (ed.), The Varieties of History (New York, 1972), p. 251.

9. See H. P. Rickman, "Geisteswissenschaften," in The Encyclopedia of Philosophy, 3-4 (1967), pp. 275-9.

10. Among other reasons, on the grounds that strictly speaking every event is "unique," whether it occurs in the "physical" or "human" realm.

11. Karl J. Weintraub, Visions of Culture (Chicago, 1966), pp. 162-3.

12. Cited in Annie M. Popper, "Karl Gotthard Lamprecht (1856-1915)," in Bernadotte E. Schmitt (ed.), Some Historians of Modern Europe: Essays in Historiography (1942; repr. Port Washington, NY, 1966), p. 223. 
13. Cited in Hans-Josef Steinberg, "Karl Lamprecht," in Hans-Ulrich Wehler (ed.), Deutsche Historiker (Göttingen, 1971), p. 64.

14. Ibid., p. 58.

15. Cited in Popper, "Karl Gotthard Lamprecht," p. 236, n. 43.

16. John Higham, History (Englewood Cliffs, NJ, 1965), p. 113.

17. James Harvey Robinson, The New History: Essays Illustrating the Modern Historical Outlook (New York, 1912), p. 73.

18. E.g., Harry Elmer Barnes, The New History and the Social Studies (New York, 1925); H. E. Barnes and Howard and F. B. Becker, Contemporary Social Theory (New York, 1940).

19. Barnes, The New History and the Social Studies, p. 11.

20. Higham, History, p. 119.

21. E.g., David Gross, "The New History': A Note of Reappraisal," History and Theory, 13 (1974): 53-8.

22. Martin Siegel, "Henri Berr's Revue de Synthèse Historique," History and Theory, 9 (1970): 332.

23. Henri Berr, "About Our Program," in Stern, Varieties, p. 253.

24. Ibid., p. 250.

25. Ibid., p. 253.

26. Barraclough, "History": 264.

27. Lucien Febvre, "History and Psychology"[1938], in Peter Burke(ed.), A New Kind of History: From the Writings of Lucien Febvre (New York, 1973), pp. 10-11.

28. David Thomson, "The Writing of Contemporary History," The Journal of Contemporary History, 2 (1967): 33.

29. Emmanuel Le Roy Ladurie, The Territory of the Historian (Chicago, 1979), p. 17.

30. Weintraub, Visions of Culture, p. 176.

31. Barraclough, "History": 229.

32. E.g., Ralf Dahrendorf, Society and Democracy in Germany (Garden City, NY, 1967).

33. Barraclough, "History": 257.

34. Ibid., 258.

35. E.g., Robert William Fogel, "The Limits of Quantitative Methods in History," The American Historical Review, 80 (April 1975): 329-50.

36. Robert William Fogel, Railroads and American Economic Growth: Essays in Econometric History (Baltimore, MD, 1964).

37. Preserved Smith, "Luther's Early Development in the Light of Psychoanalysis," American Journal of Psychology, 24 (1913): 360-77; Erik K. Erikson, Young Man Luther: A Study in Psychoanalysis and History (New York, 1958).

38. Donna Arzt, "Psychohistory and Its Discontents," Biography, 1 (Summer 1978): 1; Bernard Bailyn, "The Challenge of Modern Historiography," The American Historical Review, 87 (Feb. 1982): 20. See also David E. Stannard, Shrinking History: On Freud and the Failure of Psychohistory (New York, 1980), and Robert J. Brugger (ed.), Ourselves/Our Past: Psychological Approaches to American History (Baltimore, MD, 1981), which defends the idea of applying psychological theory to history and includes a number of exercises in the method.

39. Le Roy Ladurie, Territory, p. 28.

40. See Richard T. Vann, "History and Demography," History and Theory, Beiheft 9 (1969): 64-78.

41. Robert Darnton, The Business of Enlightenment (Cambridge, MA, 1979).

42. Le Roy Ladurie, Territory, pp. 287-319. 
43. Isser Woloch, "French Economic and Social History," The Journal of Interdisciplinary History, 4(Winter, 1974): 435-8; Michael Kammen, The Past Before Us: Contemporary Historical Writing in the United States (Ithaca, NY, 1980), p. 26.

44. E. H. Carr, What Is History? (New York, 1961), p. 80.

45. A. O. Lovejoy, "Reflections on the History of Ideas," Journal of the History of Ideas, 1 (Jan. 1940): 4.

46. G. R. Elton, The Practice of History (New York, 1967), p. v. Elton is a staunch defender of old-fashioned "political history." It is interesting to note that similar attitudes toward philosophy prevail even among methodological innovators. Fernand Braudel, Febvre's successor as chief of the Annales school, has reservations about a philosohical approach because he thinks it encourages a "tendency to see history as a discipline whose rules have been defined utterly and once and for all" $(O n$ History [Chicago, 1980], p. 64). Pierre Chaunu, a quantifier and leading member of the Annales group, has said that "Epistemology is temptation one must resolutely cast aside .... At most it is opportune that a few leading minds dedicate themselves to it ... in order to preserve the robust craftsman who is busy forging a knowledge still under construction ... from the dangerous temptations of this deadly Capoue [Capua, Italy]" (cited by Paul Ricoeur, The Contribution of French Historiography to the Theory of History [Oxford 1980] p. 33, n. 2). Ricoeur (p. 33) refers to the "deliberately anti-epistemological attitude of French historians." Even Barraclough ("History": 271), an unrestrained admirer of modern techniques, believes that critical philosophy of history "is of greater interest to philosophers than to historians seeking new ways forward."

47. C. Vann Woodward, "History and the Third Culture": 24. The situation may be changing to some extent. Kammen, The Past Before Us, p. 31, believes that the 1970s witnessed a "revolution in methodological awareness," reflected in the "burst of books on how History ought to be done; in the proliferation of new journals that emphasize methodology; in books and essays that plead for greater self-consciousness on the part of historians about their assumptions and procedures; and in the appeal being made by some that historical methodology itself be recognized as a discrete subdiscipline." Nevertheless, the message on the portals of philosophy is still Eintritt Verboten; as Kammen (p. 32) notes, "Few historians have been impelled, contrary to what one might have expected, to take a greater interest in the philosophy of history." Moreover, it is still difficult to say if the discussions of philosophers and epistemologically inclined historians have had any actual impact on the way most historians "do" history. Historians are still generally "schizophrenic" about the subject.

48. White, Metahistory, p. ix.

49. E.g., Nancy Struever, The Language of History in the Renaissance (Princeton, NJ, 1970); White, Metahistory; Lionel Gossman, "Augustin Thierry and Liberal Historiography," History and Theory, Beiheft 15 (1976): 3-83; see also the essays in Robert H. Canary and Henry Kozicki, The Writing of History (Madison, WI, 1978).

50. See $A H A$ Perspectives, 21 (Feb. 1983): 8-9. Not every year has witnessed the selection of such a high proportion of works resting on interdisciplinary scholarship and conceptualization. It is doubtful, for example, if any of the prize-winning books for 1983, described in the February 1984 issue of $A H A$ Perspectives, would qualify as "interdisciplinary." The nature of the selections obviously varies with the composition of the selection committees. However, a survey of the past ten years will reveal a significant number of interdisciplinary choices. 